\title{
Taboo Readings, Willful Girls
}

\author{
Linda Laidlaw, $\odot 1999$
}

There are some things you must never say. Secrets you must never share. The stories you think cannot be true-it could not have happened that way, I must be mistaken.

Taboo readings. Willful girl-children. Willful, curious, but careful to conceal our knowledge of a hidden, adult world. Forbidden books and magazines. Forbidden not only for us, we knew, because we always found them in the most unlikely places. In the basement, under cans of old paint. Underneath or behind sofas. Under, behind, this reading material was always buried where no one would encounter it by accident. There was always a sense of shock and amazement at what we discovered, and a thrill of knowing a powerful secret. Something dangerous, some particular badness that, for once wasn't us. We knew secrets about the adults in our lives. But, there are some stories you do not tell. Stories you hide away behind the rusted paint cans. You shut them away in your memory until you wonder if they really happened at all. And you never ask the dangerous questions that lurk in your curious mind....

$\mathbf{I}$ grew up in a small town, a place full of churches. The main highway through town held some kind of record for the number of churches on one street. It was a place where you knew almost everyone, or if you didn't know someone, you'd heard something about them. It was a place in the heart of the Sunny Okanagan where folks escaped the city or the cold to raise children or retire.

Most of my friends had strict parents, parents who were particular about what these girls did and how they behaved, and seemingly more concerned about moral development and "appropriate" reading materials than my parents were. Debbie's father was a Baptist minister and he actively censored her books. (He tore apart her copy of The Exorcist and tossed it in the garbage. Debbie later reassembled the book but never did find page 25.) Susan's parents were teachers, both active in the music and church community - they insisted she read Classic Literature, whatever that was. Susan had her own library of leather bound books: Robinson Crusoe, Heidi, Alice in Wonderland, Little Women. Even her comic books were from that classics comic book series, unlike the tattered Archie and Tales from the Crypt comics I owned.

My mom came from the "wrong side of the river" in Edmonton, growing up in a three room shack with no running water or electricity, and had herself experienced little in the way of parental supervision in her own childhood. My father considered the care and moral development of girl children generally best left to my mother. He didn't much believe in church attendance, being more-or-less a closet atheist. My parents' approach to child rearing could probably be categorized as benevolent neglect. There was lots of freedom, and a parental aversion to supplying guidance except where absolutely required by issues of cleanliness or bad manners. My parents didn't often voice an opinion on my reading except when I read at the table and spilled, something which happened fairly often. They were readers themselves, though my parents generally preferred nonfiction to novels-I was the family aberration as a fiction enthusiast. My interest in books was fed by weekly visits to the public library where, by the age of eleven, I'd read everything in the children's department and continued on into the "adult" section (feeling terribly insulted that the librarian had insisted on having parental permission for me to do so). My parents did not pay any particular attention to what I read, whether it was a year-long interest in ghost stories and the occult, or an obsession with science fiction and fantasy. No, they commented only when my growing piles of library books got in the way of cleaning or 
hallway mobility.

The only time I remember anyone trying to prevent me from reading a particular book was when my mother was reading Erica Jong's Fear of Flying and said, "I don't want to catch you reading this book."

So I didn't let her see me reading it, I read it furtively when she left the house. I was always careful to keep her place marked and to return the book exactly as she'd left it which was usually under a rumpled dishtowel in the kitchen. My curiosity was piqued by my mother's odd behaviour concerning this book and by the content of the book itself. But there was no place for my questions since asking them would reveal my own transgression in reading the forbidden text. My mother was, after all, the same woman who had explained the 'facts of life' to my sister and me by reading us a book (I'm sure you know the one) that had pictures of chickens, one on top of the other, and people lying close together, but not quite touching, under a large blue blanket. No actual body parts were visible or even assumed to be present though I think there may have been a few 'scientific' diagrams of some inside bits. This book caused us no small bit of confusion a little later on, as my sister and I both believed for a time that one might become pregnant by sitting too close to boys, a belief which seemed to be verified by the teen-age pregnancies of two of our older "boy-crazy" cousins. Talk of reproduction, sex, or the erotic seemed to be an area that made adults uncomfortable and evasive, responses which fueled my curiosity and created a kind of hunger for more information. Being an avid reader, I was thus inclined to look for answers in books.

I suppose, in addition to my own quest for knowledge, it was a sense of mystery, the unknown, the forbidden, that drew Susan, Debbie and me into our search for "taboo" reading materials. The friendship between us had always been based on our kindred interests in books: earlier, the Bobbsey Twins and Nancy Drew, later the Little House, Narnia, and Tolkien books, assorted mysteries, stories of magic, fantasy, and adventure. As we approached puberty we read Judy Blume and sought out more "adult" books, particularly those with scenes of romance; mainly we read for technical details and information. It was reading as research-our teachers should have been proud. Our contraband reading discoveries may have resulted from our search for adult books that contained sex scenes though it's also possible we may have stumbled upon the hidden caches of erotic reading materials by accident, I do not remember exactly how it started.... Eventually though, we found "forbidden" texts in all of our houses as well as in the homes of the prominent community members who employed us as babysitters. Imagine our surprise.

HEY! Look at THIS!" Susan fingered the stack of Playgirl, Penthouse, and Playboy magazines discovered behind the couch at the house where our English teacher and her husband lived. The Playgirl was what really shocked us-Mrs. V. just did not seem the type to be looking at pictures of naked men. She was a teacher, after all. And a mother of a baby girl and a preschooler. Someone we couldn't imagine having any sort of sex life. Having not seen very many naked male adults before, we poured over the pictures, fascinated, embarrassed, and disgusted.

After the initial shock of our discovery had worn off, and our laughter had died down, we studied the pictures carefully.

"You know, I didn't think they would be quite that ugly...." reflected Debbie.

"I just don't know how people can ever stand having sex. I mean, wouldn't you just want to burst out laughing looking at that!" said Susan, pointing.

"Maybe that's why everyone 'does it' in the dark," I replied. 
Overcome with much laughter at imagining adults having sex, we attempted to regain control so we would not wake the sleeping children, and then returned the magazines to their hiding place, careful to leave no evidence that might point to our discovery of them. But those magazines were revisited in future babysitting engagements as we sought to find answers for some of our questions. Perhaps if we read the printed text, the articles, the letters to the editor, we would learn more.... Perhaps, too, we might find an answer to the question that none of us voiced, but all of us were thinking: How could Mrs. V. be reading a magazine like THAT?!

I'm sure our English teacher never really knew quite how much she actually contributed to our education. She certainly never did find herself short of available babysitters.

Mrs. V.'s collection of Playgirl_-well, we assumed it was hers-was the more rare example of the pornography we discovered, material which belonged to women, presented with women in mind. Most of what we encountered had men as the intended audience (and most certainly not thirteen-year-old girls). We found magazines, pictures, and paperbacks - the books were more confusing than the photographs, evoking a number of questions for us. And of course, we had no way to find answers without stirring up trouble for ourselves. Why was it that the women in these books seemed to be regarded with disdain, or as some kind of prey? Is that what men really think about women? Will we have to be like the women in those books? We began to wonder about our place in the world, this new world we had stumbled upon.

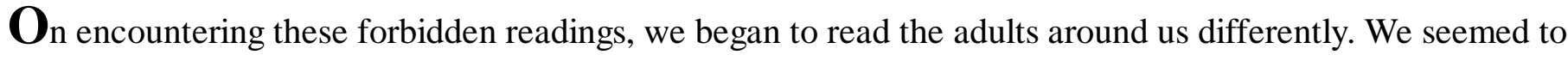
have discovered a darkness that lurked within that we'd never previously suspected in our lives as children. These adults who at times attempted to control our own behaviour, particularly how we behaved where boys were concerned, looked perfectly normal from the outside rather than the sex fiends we were coming to imagine. Although there was a certain thrill to our discoveries, to sharing these secrets together, there was also a sense of hypocrisy and betrayal. Most of the time what we discovered were books and magazines belonging to our own fathers or other people's fathers. And women generally didn't seem to be doing very well in these reading materials.... What were these concealed readings saying about us as future women? About the fathers and the other adults we thought we knew? Our reading of the world, the world for girls, took on a new, vaguely ominous interpretation.

I was secretly relieved when one of the books we discovered at my house was no longer to be found. Yet I still wondered about it. How did it get there in the first place? Did it belong to my father? (It was his bookshelf, after all.) Or, did someone happen to leave it at our house accidentally? This was what I hoped, secretly, though I knew it to be an unlikely option. In this book the women were all naive and stupid, the men were superior, and certain body parts took on a central role. Certain parts of certain bodies had more power, certain other parts seemed to have less - the parts that belonged to us, to women.

To o ask my questions, to speak of the taboo book would have resulted in some hysterical scene or so I imagined-so I said nothing. Perhaps I simply did not want to know, to have my suspicions confirmed, for what then would that say about me, a girlchild nearly grown? And what about my father-was this book some kind of evidence of what he actually thought about women? Seeds of unsettling doubt were planted.... But I was not so careful as to place this paperback where it had been, before-I left it visibly on the shelf. Daring someone to notice, to respond. To say something. And the book disappeared without comment. Simply disappeared. Someone must have taken it away - was it my father, my mother? I scrutinized them carefully over the following weeks, searching for some indication, some knowing look. Something to prove it had happened, for after a while I began to wonder if the book had actually existed-perhaps it had been some figment of my imagination. Though, I still remembered those stories.... 
And then there were the books belonging to Susan's father, who taught at the local junior high that we all attended. We'd heard the stories about him, whispered in hallways, exchanged on the long walk home. Stories from school, rumours, and what we'd seen or experienced for ourselves. Teen-age girls knew to give Susan's father a wide berth for he seemed to have a problem with clumsiness that inevitably resulted in "accidental" touching-his "clumsy" hands had a tendency to make contact with the breasts of pretty girls. No one could be THAT awkward. My mother, all the mothers, thought Susan's father was a nice man, so friendly and polite.... But his collection of pornographic reading materials was the most extensive of all those we discovered, and the books he possessed seemed to go beyond the usual range of illicit reading we'd encountered. His books, after the first thrill of finding the hidden reading life of yet another adult, gave us a creepy feeling because some of his books and magazines seemed to be about $\underline{\text { us}}$, not adult women-we were beginning to realize that the world was not always safe for girls, willful or otherwise. Our search for taboo readings stopped at Susan's house-the game no longer seemed to be much fun. We kept silent about Susan's father and the reading materials he had hidden away in his workshop under the toolbox and in his office filing cabinet. We did not know how to read this situation, what to ask or tell. And who could we tell, without revealing our own transgressions? So, we went on to other things and forgot what we had seen. Or near enough to forgetting-if you cannot speak it, it may cease to exist.

There are some things you must never say. There are secrets you must never tell. For there may be trouble. Reading can get you into a mess of trouble. They never tell you that when you learn to read do they? It's not a part of reading instruction, a warning to beware of the words and images you will encounter. Though perhaps there was a message in Dick and Jane. "See Dick. See Jane. Look, look, look! See, see, see!" And so we did. Those willful girls, those curious girls who look where they should not, who see what was hidden, who learn to read the world with eyes which have seen. Those girls read the readers and find themselves betrayed.

Much later, I think about those taboo readings we'd uncovered all those years ago when my friends (whatever did become of them?) and I were growing up. Lacking any sort of adult-guided interpretation, we'd developed our own versions of what those texts really meant and new interpretations of the adults in our lives. Our experiences with the taboo materials began to unravel the seamless view we'd had of parents, teachers, adults. We discovered that they had secrets of their own, that secrets were not only a legacy of childhood. There was a multiplicity, and sometimes a duplicity, to the adults in our lives; there were other selves that had not been revealed to us as children.

Childhood, as we knew it, was over. Life was suddenly and irreversibly complicated by the taboo readings - one couldn't simply rely on what was portrayed in public or on the words which appeared on the surface. One needed to search out the hidden texts, the less visible complexities and contradictions which made up the people who populated our lives. Interpreting who these adults presented themselves to be was a bit like reading a fictional character in a novel, one could not know for certain what might lurk below, unseen, in the spaces between the lines.

Though the discoveries of the taboo readings seemed rather like biting into the mythic apple and finding that adults and my world did not exist as I had previously imagined them to be, there was also an odd sense of relief that eventually followed. If the adults surrounding me were not perfect models of truth and morality, if they had secrets - then perhaps I need not worry quite so much about my own little secrets and transgressions. As well, the taboo readings made visible a part of the world which had been unarticulated, but somewhat suspected. As Madeleine Grumet writes, referring to "the unspoken" in schools," 
And then there's all the stuff nobody says to anybody. The parts of the world that are not spoken do not disappear. They are still there in the streets, on TV, and at home when school is over, and things both said and unsaid whisper in our minds....

Perhaps the difficulty, after all, was not in the taboo readings themselves, but in the veil of secrecy which kept them hidden and inaccessible to comment or analysis, a secrecy that seemed to silence the adults to whom these materials belonged.

It has been years since my own taboo reading discoveries, but it does not seem that things have changed very much for children or adolescents, particularly in terms of reading. The practice of 'protecting' children and adolescents from controversial sorts of reading materials seems to be alive and well though, ironically, any child with access to cable television or the Internet can engage in a more thorough and detailed research of sexual images, information and practices than was possible in my own childhood. As I write this, I am aware of a number of current books-books which make reference to issues of sexuality or notions of nontraditional family structures - which have been banned or recently challenged by school boards or parent groups as unsuitable for children or adolescents. What we keep secret, hidden, away from scrutiny, will not eliminate the existence of those things. Instead, what is most certainly stifled is the opportunity for intelligent and informed discussion, something which may have more serious consequences when children and adolescents must construct their own interpretations in secrecy. By making particular texts less accessible (or taboo), one also creates an aura of mystique and increases their appeal. What we're drawn to is the secret, the 'naughty bits.'

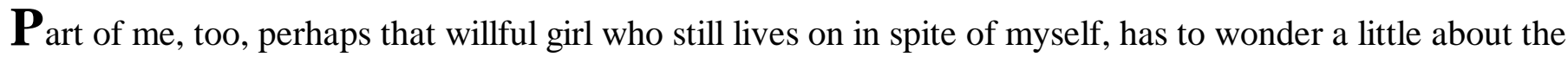
books and magazines which might be uncovered in the homes of those individuals who propose such censorship. It's a funny thing, we always seemed to find those taboo readings in the most unlikely places....

\section{Linda Laidlaw}

